\title{
Reserve Currency Status as a Safe Asset Determinant. Empirical Evidence from Main Public Issuers in the Period 2005-2017
}

\author{
Joanna Bogołębska \\ Ph.D., Associate Professor, University of Lodz, Faculty of Economics and Sociology \\ International Business and Trade Department, Lodz, Poland \\ e-mail: joanna.bogolebska@uni.lodz.pl
}

\section{Ewa Feder-Sempach}

Ph.D., Assistant Professor, University of Lodz, Faculty of Economics and Sociology International Finance and Investment Department, Lodz, Poland

e-mail: ewa.feder@uni.lodz.pl

\section{Ewa Stawasz-Grabowska}

Ph.D., Assistant Professor, University of Lodz, Faculty of Economics and Sociology International Finance and Investment Department, Lodz, Poland

e-mail: ewa.grabowska@uni.lodz.pl

\begin{abstract}
Safe assets are recognized as being the cornerstone of contemporary financial systems. Due to financial globalization and massive international capital flows, they transformed into global safe assets, meaning that both demand and supply sides can be created by international investors. The article consists of two main parts. The first one concentrates on the theoretical issues of safe assets: definitions, attributes, categories of investors who search for them, as well as categories of suppliers. The theoretical considerations lead to the conclusions that only debt instruments can be used as safe assets, and due to limited substitutability between private and public issues, only the latter can perform this function properly, especially in times of stress. In the context of global safe asset considerations, it seems reasonable that only countries issuing reserve currencies can become public issuers of safe assets.

The empirical analysis presented in the second part of the article confirms the theoretical predictions. A study of sovereign bond yield differentials conducted for two groups of countries (issuers of reserve currency and non-issuers but possessing the
\end{abstract}


highest credit ratings) shows that in the period 2005-2017, the spreads in the first group were depressed by the mere fact they held the status of a reserve currency issuer.

Keywords: safe assets, developed economies, government bonds, reserve currencies

JEL: E51, E58, E63, F33

\section{Introduction}

When considering the determinants of safe asset creation, one must take into account both a set of macroeconomic determinants and a behavioral determinant, which is connected with the status of the reserve currency. The uniqueness of the latter stems from the fact that investors' sentiment rather than macroeconomic fundamentals decides which assets are labeled safe. Due to inertia in the international monetary system, investors' sentiments towards reserve currency do not change in accordance with the economic stance of the issuers. This is why reserve currencies become safe havens in times of financial stress.

\section{Safe Assets: Notion, Criteria, and Attributes}

The international specialist literature does not offer a uniform definition of safe assets. Definitions adopted in individual publications differ as to how they present the sources of supply of safe assets, their qualities and attributes.

The notion of safe assets has featured in the economic literature for some decades to describe low-risk investments. Yet, it took the Global Financial Stability Report published in 2012 by the International Monetary Fund (IMF) to draw attention to the relevance of safe assets for the global financial market. By recognizing safe assets as a cornerstone of the contemporary financial system, the Report systemizes the notion, analyses the supply and demand sides of safe assets, and lists their main functions. The Report is the key reference point for further analyses in this field.

Safe assets are commonly defined as any debt instrument which guarantees a fixed amount of money in the future, free from the risk of the issuer's insolvency. The IMF highlights two fundamental attributes of safe assets: a steady income stream and the ability to preserve portfolio values (IMF 2012, p. 90).

Gourinchas et al. (2012, p. 5) define safe assets as a liquid claim with negligible default risk. It is a debt instrument which guarantees a fixed amount of money in the future. They also identify three sources of safe assets supply:

- central bank liabilities (cash including insured deposits),

- government (sovereign) debt,

- private assets market. 
The above classification suggests that potentially safe assets can be issued by central banks, sovereign, and the private sector. They can take the form of cash or any debt instrument that is tradable, liquid, and with the highest credit rating. The IMF (2012, p. 81) admits that there are no risk-free assets that would offer total safety. At the same time, it makes reference to links between safe assets and credit rating; according to the IMF, the safety of an asset should not be directly linked with its rating since the latter only reflects the market perception of an asset's safety. By the same token, the IMF defines safe assets in the light of attributes that they must have. Safe assets should meet the following five criteria:

1. Low credit and market risks.

2. High liquidity.

3. Limited inflation risk.

4. Low exchange rate risk.

5. Limited idiosyncratic risk.

From the viewpoint of asset safety, the first criterion is crucial because lower credit and market risks are usually linked with higher liquidity. On the other hand, there are instances when safety and liquidity do not go hand in hand. For example, some safe assets owe their low market liquidity to their construction (e.g. insured saving deposits). On top of that, in times of crisis, some high-risk assets (e.g. shares) may be more liquid than corporate bonds or rated ABS (Golec et al. 2017, p. 7), which are usually considered safer.

The importance of credit risk is also highlighted by Golec et al. $(2017$, p. 5) in their definition of a safe asset, understood as an unconditional financial liability free from credit risk, which guarantees the repayment of nominal value. This is how these authors classify any debt issued or secured by a "safe" government, i.e., a government of a country having its own credible central bank, stable currency, and effectively protecting property rights (Golec et al. 2017, pp. 4-5).

The relevance of individual IMF criteria should be seen in the context of investor category. For instance, to investors in long-term liabilities (e.g., pension funds, insurance institutions) liquidity is less important, which is why they see less liquid assets with longer maturity periods as safe. Investors in long-term safe assets pay more attention to the risk of inflation while market players involved in exports and imports carefully monitor exchange rate developments.

Together with the growth of the global financial and economic system, since the $17^{\text {th }}$ century, safe assets have evolved into debt instruments. Hence a question arises as to why debt is a claim best placed to become a safe asset. Surely it is because of its attributes; debt claim is the least sensitive to a change of value. It is also relatively resilient to negative selection and moral hazard. Moreover, debt has the following attributes:

- it is insensitive to information. It is the effect of the issuer's credibility, which reduces investor's cost of collecting information about the value of an asset in question and eliminates information asymmetry. This quality of safe assets is referred to as NQA - No Question Asked (Holmstrom 2015); 
- strategic complementarity, meaning that an asset is safe if others expect it to be safe (Farhi 2016);

- the issuer's reputation and history matter when it comes to expectations vis-à-vis asset safety (Caballero et al. 2017, p. 30).

The relevance of the above attributes was captured in the definition by Caballero et al. (2017, p. 29), according to which a safe asset is a simple debt instrument that is expected to preserve its value during systemic crises.

The fact that in the early 1950s demand bank deposits were generally considered a safe asset only confirms that the notion has evolved with the development of the international financial environment (Caballero et al. 2017, p. 40).

\section{Safe Assets: Demand Considerations}

Safe assets perform different functions in global financial markets. Investors demand safe assets as they seek to find a reliable store of value, stable collateral in derivatives market transactions as well as in other private and central bank transactions (repo transactions), to meet prudential requirements. They are also used as benchmarks in the valuation of other, riskier assets. Safe assets are substitutes of trust in financial markets and, above all, they are crucial components of monetary policy operations.

Table 1 presents a variety of motivations that drive investors' demand for safe assets. Demand shaping factors also inform us whether an investor is interested in a short-term or long-term asset. Short-term assets, which can be readily converted into cash, are used mostly for transactional purposes while long-term assets serve as a store of value or are used as collateral for financial transactions.

Banks are investors whose share is the biggest in the total stock of safe assets (IMF 2012 , p. 89). Their demand for safe assets is motivated by, inter alia, misalignment management strategies, performing the function of a primary dealer and market-maker, using them as collateral in repo transactions and in derivatives markets, and obligation to meet prudential requirements.

It is anticipated that bank demands for government debt will rise in the years to come. That is due to the entry into force of new regulations, such as the Basel III Liquidity Coverage Ratio, which require banks to hold a bigger stock of safe assets.

When analyzing central banks' demand for global safe assets, attention should be paid to the hierarchy of goals applied by these institutions when constructing their foreign reserves portfolio: safety, liquidity, and the rate of return. From the viewpoint of the central bank, liquidity, low credit, and market risk are crucial for identifying the scope of the safety of assets, which must be readily converted into cash and remain resilient to the loss of value. The intensive accumulation of foreign exchange reserves pursued by central banks (mainly in China and in the Asian emerging market economies) and expected growth in the scale of accumulation of foreign exchange reserves 
(on the side of central banks and their "close substitutes", i.e., sovereign wealth funds) in combination with the inability of these countries to generate safe assets pose a serious problem for the supply of safe assets and the resultant question about the stability of the international financial system. By increasing the demand for safe assets, in particular, in treasury debt securities, central banks as public institutions reduce the supply of safe assets available to private investors. As a result, private investors are squeezed out of the treasuries market towards (quasi) safe claims vis-à-vis the private sector (Golec et al. 2017, p. 15).

Table 1. Demand factors and investor categories

\begin{tabular}{|c|c|}
\hline Demand factor & Investor category \\
\hline \multirow[t]{4}{*}{ Store of value } & $\begin{array}{l}\text { Foreign exchange reserve managers (central } \\
\text { banks, sovereign wealth funds) }\end{array}$ \\
\hline & Insurance companies and pension funds \\
\hline & Non-banking financial institutions \\
\hline & Retail corporations \\
\hline $\begin{array}{l}\text { Collateral for financial transactions, portfolio } \\
\text { hedge }\end{array}$ & Banks and other financial institutions \\
\hline \multirow[t]{2}{*}{ Baseline value in prudential regulations } & Banks \\
\hline & Insurance companies and pension funds \\
\hline $\begin{array}{l}\text { Monetary policy conduct, source of liquidity } \\
\text { in crisis management }\end{array}$ & Central banks, monetary authorities \\
\hline Benchmark for other assets & Banks and other financial institutions \\
\hline \multirow[t]{2}{*}{ Payments, transactional reserves } & Banks \\
\hline & Retail clients, corporations \\
\hline
\end{tabular}

Source: authors' own compilation, see: IMF (2012), Gelpern and Gerding (2016).

The demand for safe assets of insurers and pension funds, i.e., long-term investors, links with their overall investment policies. Yet, one needs to bear in mind that in a prolonged low-interest-rate environment, these institutions are likely to search for yield, which is why their demand for safe assets may decrease (ESRB 2016).

When analyzing the demand for safe assets, we need to stress that it strongly depends on the business cycle in the global economy. Over the last three decades, several periods can be distinguished:

1. From the mid-1990s - a strong demand of foreign central banks accumulating foreign exchange reserves.

The dynamic accumulation of foreign exchange reserves was triggered in relation to the currency crisis in South-East Asia in 1997-1998. In the countries most affected by the crisis (such as South Korea, Singapore, or Thailand) prudential demand plays the dominant role: reserves are accumulated to prevent destabilizing flows of short-term capital. In China, which holds the largest foreign exchange reserves in the world, mercantilist motive plays the most prominent role. The accumulation of reserves is supposed to enable China's foreign exchange interven- 
tions to maintain the price competitiveness of Chinese exports. In total, over the period 1996-2017, global reserves increased from USD 1.6 trillion to 11.4 trillion (Internet source 2). ${ }^{1}$

2. In the years 2002-2007 - the demand of the financial sector.

At the same time, we need to note that in the leading global economies (the USA, the United Kingdom, France, and Germany), the demand of the private real sector remains at a stable level around ca. 80\% of GDP (Gourinchas et al. 2012, p. 7). The only exception is Japan, for whom this ratio exceeded $200 \%$ as far back as the early $21^{\text {st }}$ century. The preferences of the Japanese private sector, especially of private households, for safe assets should be linked with their perception of safe assets in connection with the demographic trends (the stable store of wealth for the aging society) and with the crisis in the early 1990s, when the materialization of risk associated with investment in less safe financial instruments was universally observed.

3. After 2007 - a strong demand posed by central banks pursuing a quantitative easing policy and the financial sector (regulatory reforms). It is also worth noting that throughout the recent crisis, investors moved capital from less liquid and higher risk investments to more liquid and safer ones. These phenomena are known as flight to liquidity and flight to safety, and they take the form of strong demand for government debt securities of the largest industrialized countries, mainly U.S. government bonds.

The analysis of the above factors, as well as globalization and the integration of financial markets, helps us understand why, in the first decade of the $21^{\text {st }}$ century, foreign economic agents increased their holdings of U.S. Treasury bonds from ca. 35\% to almost 54\% (Warnock 2010, p. 4).

Moreover, the above data highlight a critical aspect of demand for safe assets, i.e., the so-called global demand component. When safe assets become global safe assets, foreign demand for them generates a considerable stream of international capital flows. Global safe assets have one more important quality: the currency in which they are issued is a reserve currency.

\section{Safe Assets: Supply Considerations}

On the supply side, attention is paid to the qualities of the issuer and of the market in which an asset is traded. Yet, the central bank's track record is equally important when it comes to its commitment regarding the exchange rate and price stability and its readiness to purchase an asset when its price drops. The IMF draws attention to four categories of alternative sources for the supply of safe assets (see Table 2). The first three are distinguished based on the issuer's category (by making reference to the classifica-

1 For more on this topic, see Bogotębska (2013, pp. 297-358). 
tion of safe asset proposed by Gourinchas et al. 2012). The fourth category comprises emerging markets.

Table 2. Main sources of safe assets supply according to the IMF

\begin{tabular}{|l|l|c|}
\hline \multicolumn{1}{|c|}{ Source of supply } & \multicolumn{1}{|c|}{ Important short- and medium-term factors } & $\begin{array}{c}\text { Expected impact } \\
\text { on supply }\end{array}$ \\
\hline Sovereign issuers & $\begin{array}{l}\text { Considerable deterioration of fiscal indicators } \\
\text { in selected advanced economies }\end{array}$ & $\downarrow$ \\
\hline Private sector issuers & $\begin{array}{l}\text { Reduced effectiveness of traditional hedging } \\
\text { instruments }\end{array}$ & $\uparrow$ \\
\hline Central banks & Crisis-induced extension of liquidity provision & $\rightarrow$ \\
\hline Emerging markets & $\begin{array}{l}\text { Restricted ability to generate safe assets (due } \\
\text { to financial development and legal infrastructure } \\
\text { considerations) and a lower degree of financial depth } \\
\text { in comparison to advanced economies }\end{array}$ & \\
\hline
\end{tabular}

Source: IMF (2012).

By distinguishing the group of emerging markets as a separate category, the IMF stresses that, currently, they fail to meet the requirements specified for issuing safe assets, but they may potentially become issuers at a later stage. This classification, considering non-uniform classification methodology (why are other groups of countries not considered if it includes emerging markets?) may lead to some controversies surrounding its coherence.

One needs to bear in mind that a country's ability to issue global safe assets is determined by the development of its financial market, the fiscal capacity of the sovereign, as well as the central bank's record in maintaining the value of the currency and the scope of its crisis management framework. For that reason, the supply of global safe assets comes from a handful of advanced economies which issue a reserve currency, mainly the USA. From the literature, we can learn that the current list of global (sovereign) safe asset issuers includes the USA, Japan, Switzerland, Germany, and, to some extent, the United Kingdom (Gourinchas et al. 2012, p. 38).

According to Landau (2013, p. 250), in the supply of safe assets, we can observe two patterns:

- safe assets have a relatively stable share in total financial assets of an economy,

- financial and government liabilities are substitutes: fluctuations in the stock of public debt crowd in and crowd out money and debt issued by financial intermediaries. Over the long run, the financial system seems to adjust so that the "constant share" law is respected.

The above patterns imply the potential subsidiarity of safe assets as debt-based instruments supplied by sovereign issuers and the private sector. However, the experiences of the global economy in generating safe assets demonstrate that they are not perfect substitutes. Private safe asset issuances are highly procyclical, meaning they cease to perform this role under conditions of financial instability. Potentially, only 
short-term debt securities issued by highly creditworthy issuers from the private sector can be regarded as safe assets (Kacperczyk et al. 2017, p. 27).

The principal problem with safe assets issued by the private sector lies with their deteriorating quality under conditions of a negative shock, that is, when they are the most needed. That is why they are referred to as quasi-safe, which suggests they are safe but outside of major crises (Golec and Perotti 2017, p. 24).

The ability of quasi-safe assets to fulfill the role of safe assets only under the conditions of relative stability is confirmed by experiences from the first decade of the $21^{\text {st }}$ century. In response to demand from abroad, between 2002 and 2007, American and European private markets provided huge amounts of (as they then believed) safe assets through the securitization of riskier financial instruments. The global financial crisis revealed that the fundamental disadvantage of debt instruments issued by the private sector lies in their vulnerability to fire sales. Such runs happen in particular when holders of short-term debt have concerns about the value of its collateral, which is also debt (Gorton 2016, p. 1). The risk of runs could be reduced, as further suggested by Gorton, if governments could, e.g., provide deposit insurance.

In other words, the experiences of the latest crisis have shown that the role of safe assets can be best played by government debt securities, which is due, in particular, to the government's power to tax (Grabowski and Welfe 2016). On top of that, as pointed out by Gelpern et al. (2016, p. 13), these are the only assets that meet all the criteria identified for safe assets (see Table 3). That is why they dominate the stock of assets that are considered safe (see Figure 1).

Table 3. Safe assets functions and the categories of financial instruments

\begin{tabular}{|c|c|c|c|c|c|c|c|c|c|}
\hline & $\begin{array}{c}\text { Sovereign } \\
\text { debt }\end{array}$ & $\begin{array}{c}\text { Claims } \\
\text { on cen- } \\
\text { tral } \\
\text { bank } \\
\end{array}$ & $\begin{array}{l}\text { Qua- } \\
\text { si-sov- } \\
\text { ereign } \\
\text { debt }^{\mathrm{a}}\end{array}$ & $\begin{array}{l}\text { Bank } \\
\text { debt }\end{array}$ & $\begin{array}{c}\text { Cor- } \\
\text { porate } \\
\text { debt } \\
\text { (AAA) }\end{array}$ & $\begin{array}{c}\text { Com- } \\
\text { mercial } \\
\text { paper }\end{array}$ & $\begin{array}{l}\text { Money } \\
\text { market } \\
\text { fund } \\
\text { shares }\end{array}$ & ABS & Repos \\
\hline $\begin{array}{l}\text { Store } \\
\text { of value }\end{array}$ & * & * & * & * & $*$ & * & $*$ & $*$ & \\
\hline $\begin{array}{l}\text { Payments, } \\
\text { transactional } \\
\text { reserves }\end{array}$ & \begin{tabular}{|c|}
$*$ \\
(short-term \\
debt)
\end{tabular} & * & * & * & & * & * & & * \\
\hline $\begin{array}{l}\text { Collateral, } \\
\text { portfolio } \\
\text { hedge }\end{array}$ & $*$ & * & * & * & $*$ & $*$ & $*$ & * & \\
\hline Benchmark & * & & & & * & & & & \\
\hline $\begin{array}{l}\text { Monetary } \\
\text { policy, } \\
\text { liquidity } \\
\text { support }\end{array}$ & $*$ & * & * & * & & $\begin{array}{c}* \\
\text { (crisis } \\
\text { facili- } \\
\text { ties) } \\
\end{array}$ & $\begin{array}{c}* \\
\text { (crisis } \\
\text { facili- } \\
\text { ties) } \\
\end{array}$ & $*$ & $*$ \\
\hline $\begin{array}{l}\text { Prudential } \\
\text { regulations }\end{array}$ & * & * & * & * & & & $*$ & * & \\
\hline
\end{tabular}

a - government agencies and local authorities, ${ }^{*}$ denotes that a given function is fulfilled Source: Gelpern et al. 2016, p. 17. 


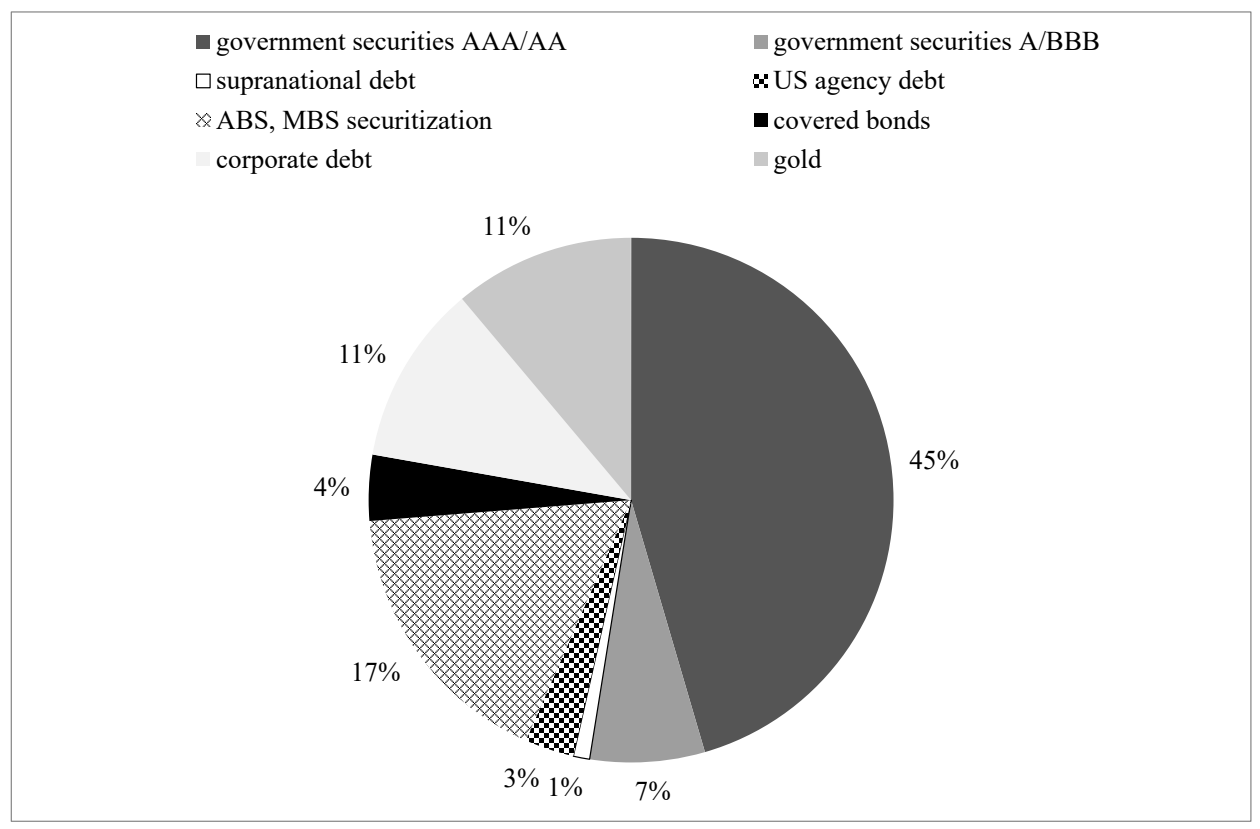

Figure 1. World's supply of safe assets

Source: authors' own compilation based on Internet source 1.

In the next section, a study devoted to the determinants of sovereign bond yields of two groups of developed economies will be carried out. The primary objective of the study is to identify the impact of the status of a global safe asset provider (or the lack of one) on a given country's bond yields, controlling for other variables reflecting credit risk, liquidity risk, and global risk aversion. The research hypothesis assumes that countries with such a status derive additional benefits in terms of perceived credibility, regardless of their macroeconomic fundamentals.

\section{Assumptions of the empirical study and research method}

1. The study encompasses developed economies (according to the OECD classification) which were divided into the following two groups:

- Issuers of reserve currencies: the United States, Germany (as the largest economy of the euro area), the United Kingdom, Japan, and Switzerland. The selection was made on the basis of IMF data on the composition of reserve assets held by the Member States of the Fund (cf. Table 4);

- Countries with the highest credit ratings: Austria, Australia, Canada, Denmark, Finland, the Netherlands, Norway, and Sweden. This group consists of the OECD countries that are not issuers of reserve currencies whose long-term ratings remain at least at the AA+ level (S\&P scale). The evolution 
of ratings between 2000 and 2017, including both the outbreak of the global financial crisis and the pre-crisis and post-crisis periods, was assessed. The analysis of Figure 2 indicates that, in principle, countries from the second group enjoyed higher ratings than issuers of reserve currencies.

Table 4. Share of national currencies in the total identified official holdings of foreign exchange (\%, end of year)

\begin{tabular}{|c|c|c|c|c|c|c|c|c|c|c|}
\hline & 2007 & 2008 & 2009 & 2010 & 2011 & 2012 & 2013 & 2014 & 2015 & 2016 \\
\hline USD & 63.9 & 63.8 & 62.1 & 62.1 & 62.6 & 61.5 & 61.2 & 63.3 & 64.2 & 63.4 \\
\hline JPY & 3.2 & 3.5 & 2.9 & 3.7 & 3.6 & 4.1 & 3.8 & 3.9 & 4.0 & 4.5 \\
\hline GBP & 4.8 & 4.2 & 4.2 & 3.9 & 3.8 & 4.0 & 4.0 & 3.8 & 4.9 & 4.7 \\
\hline $\mathrm{CHF}$ & 0.2 & 0.1 & 0.1 & 0.1 & 0.1 & 0.2 & 0.3 & 0.3 & 0.3 & 0.3 \\
\hline EUR & 26.1 & 26.2 & 27.7 & 25.7 & 24.4 & 24 & 24.2 & 21.9 & 19.7 & 20.2 \\
\hline Other & 1.8 & 2.2 & 3.0 & 4.4 & 5.5 & 3.3 & 2.9 & 3.1 & 3.1 & 3.0 \\
\hline
\end{tabular}

* The IMF countries that provide information about the currency composition of their foreign exchange reserves. Percentages may not add up to $100 \%$ due to rounding.

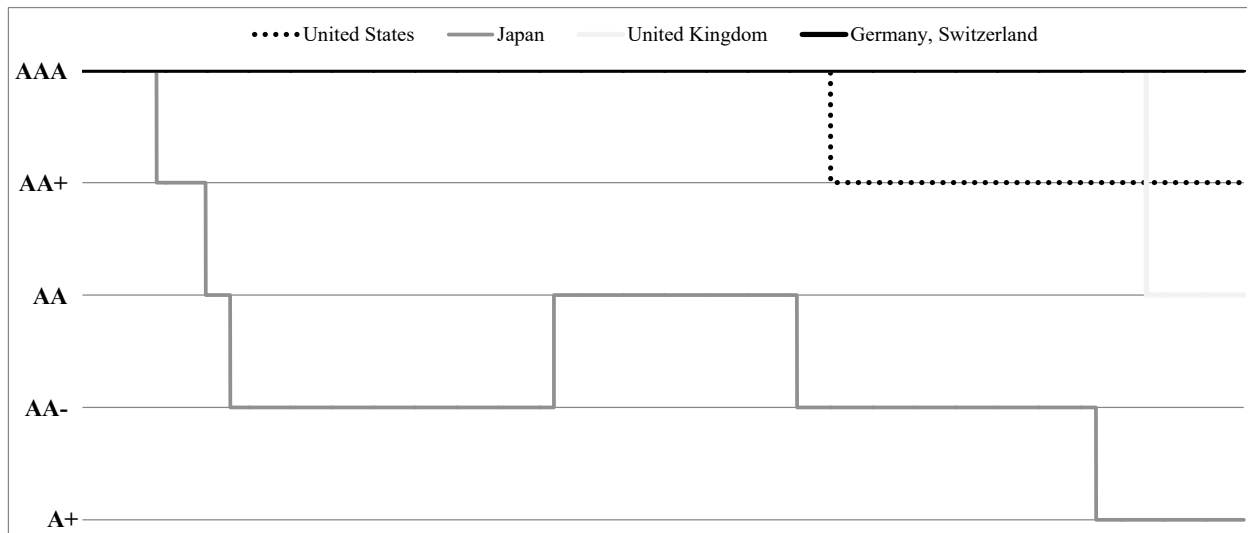

$\mathbf{A}$

$$
\text { A- }
$$

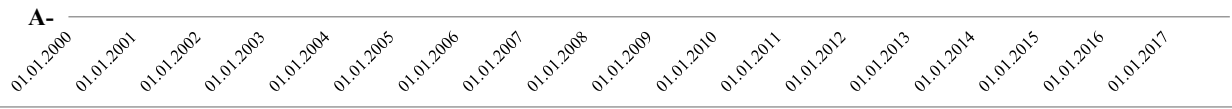

Figure 2. Credit ratings of issuers of reserve currencies

Source: Thomson Reuters Eikon.

2. The research period covers the years 2005-2017. Both the choice of the lower and upper bounds was determined by the availability of data. The data frequency is quarterly. 
3. Taking into account the conclusions derived from the extensive literature devoted to the determinants of government bond yields of developed countries, as well as the ongoing observation of processes occurring in the global economy, and also based on the availability of data, the following set of variables was created.

- The dependent variable: the spread between the yields of 10 -year government bonds of the countries included in the analysis and Germany. The choice of a 10-year bond yield was made for comparative purposes, as it is considered in the majority of similar studies. For analogous reasons, German government bond yields were adopted as a measure of the risk-free rate (cf. Kilponen et al. 2015).

- The explanatory variables. The structure of the set of the explanatory variables is based on the results of previous studies which indicate that the spreads are, to a large extent, determined by three main risk factors, i.e., credit risk, liquidity risk, and global risk aversion. In the current study, the first of these factors is approximated by the ratio of general government debt to GDP (Debt) and current account balance to GDP $(C A)$. Additionally, variables that reflect the economic situation of the issuer were included: GDP growth $(G D P)$, unemployment (Unemployment), and inflation (Inflation). In the literature, bid-ask spreads (cf. e.g., Bernoth and Erdogan 2012; Beirne and Fratzscher 2013; Alessandrini et al. 2014) or the size of the bond market (cf. e.g., Arghyrou and Kontonikas 2012; Bernoth et al. 2012) are usually used as an approximation of (difficult to capture) liquidity risk. In this study, it was decided to use the first of those proxies (Bid_ask). Global risk factors are reflected in the VIX in$\operatorname{dex}(V I X)$ from the CBOE. It is often used to proxy the risk appetite of international investors (cf. e.g., Barrios et al. 2009; Arghyrou and Kontonikas 2012; Giordano et al. 2013).

The data were obtained from the OECD and Thomson Reuters Eikon databases. Appendix 1 presents basic descriptive statistics for the dependent variable and explanatory variables. The expected impact of potential determinants on the spreads is also presented (cf. Table 7, Table 8).

The following model is considered:

$$
\begin{gathered}
\text { Spread }_{i t}=\alpha_{0}+\alpha_{1} * \text { Debt }_{i t}+\alpha_{2} * C A_{i t}+\alpha_{3} * G D P_{i t}+\alpha_{4} * \text { Inflation }_{i t}+ \\
\alpha_{5} * \text { Unemployment }_{i t}+\alpha_{6} * \text { Bid_as }_{i t}+\alpha_{8} * \text { VIX }_{t}+\varepsilon_{i t}, \ldots \ldots \ldots \ldots \ldots \ldots \ldots \ldots \ldots
\end{gathered}
$$

where $i$ and $t$ index countries and quarters respectively.

In order to choose between different variants of panel models (no effects, with fixed effects, and with random effects), standard tests were carried out: the F-test, the Breusch-Pagan test, and the Hausman test. The test results are presented in Table 5. It turns out that the model with fixed effects (in terms of countries) is "the best". 
Table 5. The results of testing of the presence of fixed or random effects

\begin{tabular}{|l|c|c|}
\hline \multicolumn{1}{|c|}{ Test } & Value of statistic & p-value \\
\hline F-test & 125.1 & 0.000 \\
\hline Breusch-Pagan test & 3795.09 & 0.000 \\
\hline Hausman test & 99.08 & 0.000 \\
\hline
\end{tabular}

Source: authors' own compilation.

Estimations of panel model parameters are included in Table 6. Fixed effects for countries are presented in Figure 3. The results obtained can be interpreted as follows.

1. For all the analyzed countries, statistically significant (as well as in line with the expected direction of impact) estimates of parameters standing at variables Debt, CA, Bid_ask were obtained. ${ }^{2}$ These results suggest that spreads of developed countries are influenced by credit risk and liquidity risk.

2. Other variables reflecting the issuer's macroeconomic condition which were included in the study proved to be insignificant.

3. Similar conclusions indicating the importance of the condition of the public finance sector and external imbalances as the main determinants of spreads are derived from the research conducted by Maltritz (2012) and Alessandrini et al. (2014). Nevertheless, it should be remembered that the studies referred to were conducted for the specific context of the sovereign debt crisis in the euro area. Thus, they were based on other assumptions, including that the analyzed countries were limited to selected euro area economies or a division into the pre-crisis and post-crisis periods. ${ }^{3}$

4. When analyzing fixed effects for countries, it is clearly visible that negative values were obtained primarily for the issuers of reserve currencies (except for the United Kingdom) and positive for countries in the second group (with the exception of Canada). The obtained result may suggest that merely (not) holding the status of issuer of a reserve currency may be conducive to depressing (increasing) spreads, regardless of the evolution of "traditional" determinants. This is in line with the research hypothesis.

5. At the same time, it should be noted that the countries' effects could also be determined by other factors. For example, in the case of Japan, spreads were definitely lower than what would have resulted from macroeconomic fundamentals - this might have been caused by the country's ultra-accommodative monetary policy (maintaining short-term interest rates close to zero and quantitative easing pro-

2 p-value for Debt and CA turned out to be very low, while Bid_ask was significant at the 0.15 level of significance.

3 On the other hand, it is surprising that in the current literature on the determinants of sovereign bond yields, very little attention is devoted to developed countries that do not belong to the euro area. Only one such study has been identified. The study was conducted for G7 countries (D'Agostino and Ehrmann 2013). 
grams; cf. Akram and Huiqing 2018) or the government putting pressure on large Japanese banks to buy domestic government bonds. The latter factor additionally influenced the decrease of interest rates on bank deposits, inducing households to change the structure of savings in favor of government bonds.

Table 6. The results of the estimation

\begin{tabular}{|l|c|c|c|}
\hline \multicolumn{1}{|c|}{ Variable } & Coefficient estimate & Standard error & p-value \\
\hline Debt & 0.015 & 0.001 & 0.000 \\
\hline CA & -0.043 & 0.006 & 0.000 \\
\hline Bid_ask & 0.017 & 0.012 & 0.150 \\
\hline Constant & 0.072 & 0.027 & 0.007 \\
\hline
\end{tabular}

Source: authors' own compilation.

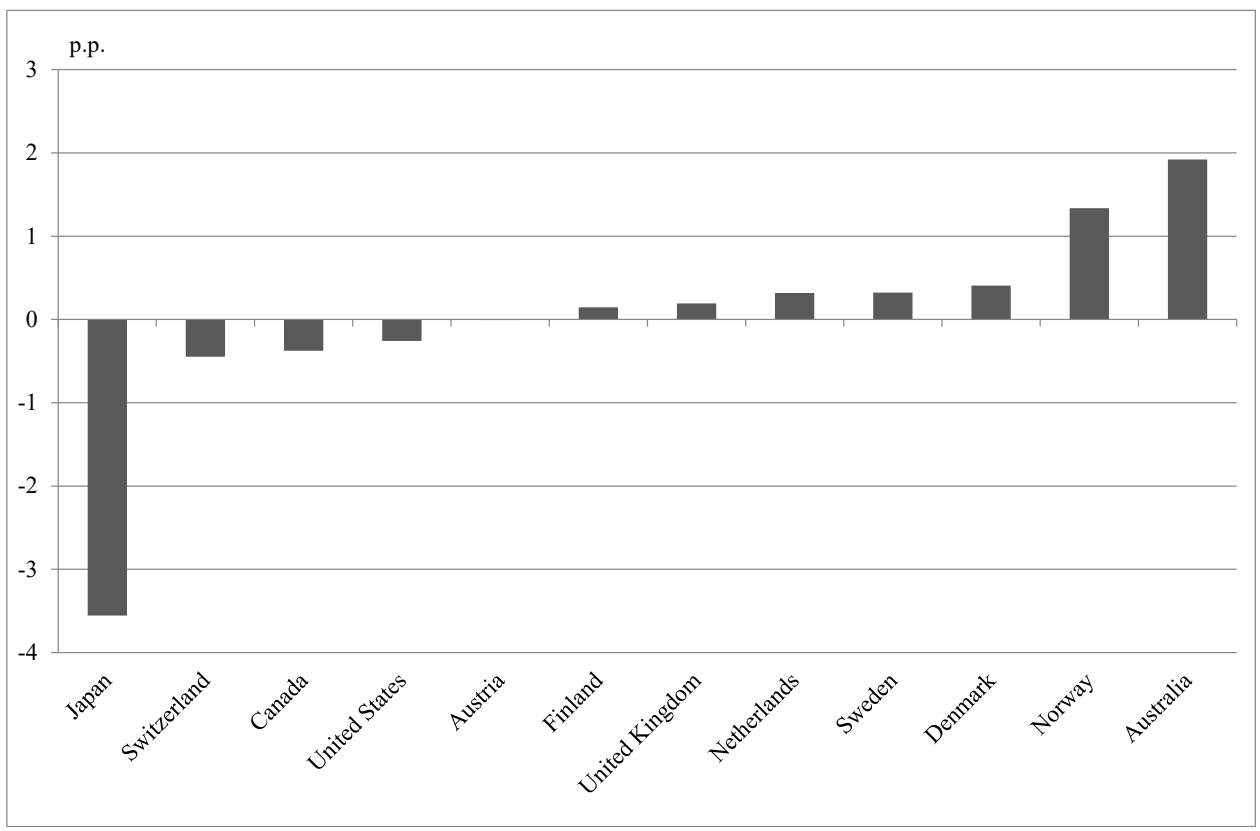

Figure 3. Fixed effects for the countries under consideration

Source: authors' own compilation. 


\section{Conclusion}

Safe assets are recognized as a cornerstone of contemporary financial systems. At the same time, the notion is difficult to define and has changed with the development of the international financial environment.

Safe assets perform different functions in global financial markets. They are used as a store of value, pledged as collateral for financial transactions, and constitute a crucial component of monetary policy operations, to mention but a few. When it comes to the supply side, it has been shown that sovereign debt instruments are best placed to play the role of safe assets. Yet, the following criteria should be fulfilled: 1) the issuer's fiscal policy must be sustainable, and 2) the central bank must have a good record in maintaining the value of the currency, and the scope of its crisis management is wide. The presented study confirms that if a country is a reserve currency issuer, it could be perceived as a global safe asset provider. This status is derived from this country's ability to issue reserve currencies.

The main conclusion stemming from the empirical study based on the panel model can be summarized as follows. In the period 2005-2017, the sovereign bond yields of two groups of advanced economies were under the influence of traditional determinants, i.e., variables reflecting credit and liquidity risks. At the same time, in the case of the USA, Switzerland, and Japan, negative country effects have been identified. This may support the claim that merely holding the status of a reserve currency issuer is conducive to depressing the yields.

\section{References}

Akram, T., Huiqing, L. (2018), The Dynamics of Japanese Government Bonds' Nominal Yields, "Levy Economics Institute”, Working Paper No. 906.

Alessandrini, P., Fratianni, M., Hughes Hallett, A., Presbitero, A. (2014), External Imbalances and Fiscal Fragility in the Euro Area, "Open Economies Review”, No. 25 (1).

Arghyrou, M., Kontonikas, A. (2012), The EMU sovereign-debt crisis: Fundamentals, expectations and contagion, "Journal of International Financial Markets", Institutions and Money, 22 (4).

Barrios, S., Iversen, P., Lewandowska, M., Setzer, R. (2009), Determinants of intraeuro area government bond spreads during the financial crisis. Brussels: European Commission, Directorate-General for Economic and Financial Affairs.

Beirne, J., Fratzscher, M. (2013), The pricing of sovereign risk and contagion during the European sovereign debt crisis, "Journal of International Money and Finance", 34.

Bernoth, K., Erdogan, B. (2012), Sovereign bond yield spreads: A time-varying coeffcient approach, "Journal of International Money and Finance", 31 (3).

Bernoth, K., von Hagen, J., Schuknecht, L., (2012), Sovereign Risk Premiums in the European Government Bond Market, "Journal of International Money and Finance", $31(5)$. 
Bogołębska, J. (2013), Nierównowagi globalne a stabilność międzynarodowego systemu walutowego, Wydawnictwo Uniwersytetu Łódzkiego, Łódź.

Caballero, R., Farhi, E., Gourinchas, P. (2017), The safe assets shortage conundrum, "Journal of Economic Perspectives", Vol. 31, No. 3, Summer.

D’Agostino, A., Ehrmann, M. (2013), The pricing of G7 sovereign bond spreads the times, they are a-changin, ECB Working Paper Series No. 1520 / march.

Farhi, E., Maggiori, M. (2016), A model of the international monetary system, NBER Working Paper 22295.

Gelpern, A., Gerding, E., Inside safe assets, Georgetown University Law Center, www. scholarship.law.georgetown.edu/facpub/1831 (accessed: 10.07.2018).

Giordano, R., Pericoli, M., Tommasino, P. (2013), Pure or Wake-up-Call Contagion? Another Look at the EMU Sovereign Debt Crisis, "International Finance", 16 (2).

Golec, P., Perotti, E. (2011), Safe assets: a review, ECB Working Paper Series, No. 2035, March.

Gorton, G. (2016), The history and economics of safe assets, NBER Working Paper, No. 22210, April.

Gourinchas, P., Jeanne, O. (2012), Global safe assets, BIS.

Grabowski, W., Welfe, A. (2016), An Exchange Rate Model with Market Pressures and a Contagion Effect, "Emerging Markets Finance and Trade", 52 (12).

Holmstrom, B. (2015), Understanding the role of debt in the financial system, BIS Working Paper, No. 479.

International Monetary Fund (2012), Safe assets: financial system cornerstone, Global Financial Stability Report.

Kacperczyk, M., Perignon, C., Vuillemey, G. (2017), The private production of safe assets, CEPR Discussion Papers.

Kilponen, J., Laakkonen, H., Vilmunen, J. (2015), Sovereign Risk, European Crisis Resolution Policies and Bond Yields, "International Journal of Central Banking", 11 (2).

Landau, J. (2013), Global liquidity: public and private, Federal Reserve Bank of Kansas City, Economic Symposium.

Maltritz, D. (2012), Determinants of sovereign yield spreads in the Eurozone: A Bayesian approach, "Journal of International Money and Finance", 31 (3).

Warnock, E. (2010), How dangerous is U.S. government debt? The risks of a sudden spike in U.S. interest rates, "Capital Flows Quarterly", Council on Foreign Relations.

\section{Internet sources:}

http://viableopposition.blogspot.com/2012/04/sovereign-debt-what-is-safe-haven.html (accessed: 12.09.2018)

www.data.imf.org (accessed: 22.11.2018). 
Joanna Bogołębska, Ewa Feder-Sempach, Ewa Stawasz-Grabowska

\section{Appendix 1}

Table 7. Definition of the variables used in the study

\begin{tabular}{|l|l|c|c|}
\hline \multicolumn{1}{|c|}{ Variable } & \multicolumn{1}{|c|}{ Description } & Source & $\begin{array}{c}\text { Expected sign } \\
\text { of coefficient } \\
\text { estimate }\end{array}$ \\
\hline Spread & $\begin{array}{l}\text { 10-year sovereign bond yield spread against } \\
\text { Germany }\end{array}$ & $\begin{array}{c}\text { Thomson Reuters } \\
\text { Eikon }\end{array}$ & n/a \\
\hline Debt & $\begin{array}{l}\text { Public sector debt, general government sec- } \\
\text { tor (\% of GDP) }\end{array}$ & OECD & + \\
\hline CA & Current account balance (\% of GDP) & OECD & - \\
\hline GDP & GDP growth rate (y/y) & OECD & - \\
\hline Inflation & Consumer price index (CPI) & OECD & + \\
\hline Unemployment & Harmonised unemployment rate & OECD & + \\
\hline Bid_ask & Bid-ask spread & $\begin{array}{l}\text { Thomson Reuters } \\
\text { Eikon }\end{array}$ & + \\
\hline VIX & $\begin{array}{l}\text { Chicago Board Options Exchange Market } \\
\text { Volatility Index (Implied volatility of S\&P 500 } \\
\text { index options) }\end{array}$ & $\begin{array}{l}\text { Thomson Reuters } \\
\text { Eikon }\end{array}$ & + \\
\hline
\end{tabular}

All variables except for VIX are taken as differences against Germany.

Source: authors' own compilation.

Table 8. Descriptive statistics for consecutive variables - means and standard deviations (SD)

\begin{tabular}{|c|c|c|c|c|c|c|c|}
\hline Spread & Debt & CA & GDP & Inflation & Unemployment & Bid_ask & VIX
\end{tabular}

\begin{tabular}{|c|c|c|c|c|c|c|c|c|c|}
\hline \multirow[t]{2}{*}{ Australia } & Mean & 2.10 & -24.74 & -10.97 & 1.20 & 1.07 & -1.31 & 0.09 & 18.74 \\
\hline & SD & 0.33 & 12.59 & 1.82 & 2.36 & 0.74 & 2.58 & 0.18 & 8.23 \\
\hline \multirow[t]{2}{*}{ Austria } & Mean & 0.35 & 6.98 & -4.16 & -0.06 & 0.48 & -1.37 & 0.15 & 18.74 \\
\hline & SD & 0.28 & 4.62 & 2.03 & 1.10 & 0.42 & 2.36 & 0.29 & 8.23 \\
\hline \multirow[t]{2}{*}{ Canada } & Mean & 0.52 & 31.35 & -8.55 & 0.35 & 0.29 & 0.39 & 0.02 & 18.74 \\
\hline & SD & 0.56 & 6.91 & 2.99 & 1.57 & 0.67 & 2.38 & 0.18 & 8.23 \\
\hline \multirow[t]{2}{*}{ Denmark } & Mean & 0.15 & -25.19 & -0.88 & -0.50 & 0.19 & -0.73 & 0.13 & 18.74 \\
\hline & SD & 0.13 & 3.42 & 2.05 & 1.48 & 0.67 & 3.23 & 0.69 & 8.23 \\
\hline \multirow[t]{2}{*}{ Finland } & Mean & 0.21 & -18.06 & -6.11 & -0.57 & 0.09 & 1.48 & 0.08 & 18.74 \\
\hline & SD & 0.17 & 10.92 & 3.10 & 1.67 & 0.82 & 2.63 & 0.29 & 8.23 \\
\hline \multirow[t]{2}{*}{ Japan } & Mean & -1.31 & 136.41 & -3.80 & -0.76 & -1.16 & -2.56 & 0.09 & 18.74 \\
\hline & SD & 0.89 & 22.42 & 1.91 & 1.67 & 1.27 & 1.91 & 0.20 & 8.23 \\
\hline \multirow{2}{*}{$\begin{array}{l}\text { Nether- } \\
\text { lands }\end{array}$} & Mean & 0.22 & -7.88 & 1.37 & -0.15 & 0.12 & -1.09 & 0.05 & 18.74 \\
\hline & SD & 0.17 & 5.55 & 2.02 & 1.45 & 0.57 & 2.85 & 0.26 & 8.23 \\
\hline \multirow[t]{2}{*}{ Norway } & Mean & 0.79 & -27.65 & 4.76 & -0.07 & 0.64 & -2.91 & -0.48 & 18.74 \\
\hline & SD & 0.40 & 11.65 & 4.90 & 2.29 & 1.37 & 2.47 & 1.92 & 8.23 \\
\hline \multirow[t]{2}{*}{ Sweden } & Mean & 0.16 & -17.78 & -0.89 & 0.58 & -0.30 & 0.85 & -0.78 & 18.74 \\
\hline & SD & 0.27 & 7.23 & 2.64 & 1.40 & 0.82 & 2.36 & 3.86 & 8.23 \\
\hline \multirow{2}{*}{$\begin{array}{l}\text { Switzer- } \\
\text { land }\end{array}$} & Mean & -0.93 & -28.24 & 3.38 & 0.37 & -1.12 & -3.41 & 0.43 & 18.74 \\
\hline & SD & 0.36 & 8.84 & 4.41 & 1.51 & 0.75 & 2.11 & 1.04 & 8.23 \\
\hline
\end{tabular}




\begin{tabular}{|l|l|r|r|r|r|r|r|r|r|}
\multicolumn{2}{c|}{} & Spread & \multicolumn{1}{c|}{ Debt } & \multicolumn{1}{c|}{ CA } & \multicolumn{1}{c|}{ GDP } & Inflation & Unemployment & Bid_ask & VIX \\
\hline \multirow{3}{*}{ UK } & Mean & 0.75 & 2.80 & -10.49 & -0.07 & 0.80 & -0.38 & 0.06 & 18.74 \\
\cline { 2 - 11 } & SD & 0.37 & 16.99 & 2.28 & 1.62 & 0.64 & 2.70 & 0.29 & 8.23 \\
\hline \multirow{3}{*}{ USA } & Mean & 0.78 & 36.49 & -9.99 & 0.21 & 0.62 & -0.12 & -0.05 & 18.74 \\
\cline { 2 - 10 } & SD & 0.75 & 16.79 & 1.26 & 1.74 & 0.85 & 3.01 & 0.19 & 8.23 \\
\hline
\end{tabular}

All variables except for VIX are taken as differences against Germany.

Source: authors' own compilation.

\section{Streszczenie}

\section{Status waluty rezerwowej a determinanty aktywów bezpiecznych Analiza empiryczna na podstawie doświadczeń emitentów publicznych w latach 2005-2017}

Artykuł składa się z dwóch części. Część pierwsza koncentruje się na teoretycznych zagadnieniach dotyczących aktywów bezpiecznych: prezentuje definicje, atrybuty, kategorie emitentów oraz inwestorów zgłaszających popyt. Rozważania teoretyczne prowadzą do wniosku, że funkcję aktywów bezpiecznych najlepiej spełniają instrumenty dłużne, a z uwagi na ograniczoną substytucyjność między emitentami publicznymi i prywatnymi, funkcję tę w największym stopniu wykonują skarbowe papiery dłużne. Co istotne, na skutek swoich specyficznych właściwości i atrybutów, na międzynarodowych rynkach finansowych dostawcami globalnych aktywów bezpiecznych są kraje emitujące walutę rezerwową.

Analiza empiryczna przedstawiona w drugiej części artykułu potwierdza opisywane zależności teoretyczne. Badanie różnic rentowności obligacji skarbowych (względem Niemiec) przeprowadzone dla dwóch grup krajów (emitenci waluty rezerwowej i podmioty niebędące emitentami, ale posiadające najwyższe oceny wiarygodności kredytowej) sugeruje, że w latach 2005-2017 spready w pierwszej grupie były zaniżane przez sam fakt posiadanie statusu emitenta waluty rezerwowej.

Słowa kluczowe: aktywa bezpieczne, kraje rozwinięte, obligacje skarbowe, waluty rezerwowe 